\title{
Anomalous Right Coronary Artery Origin
}

\author{
Solomon W Bienstock ${ }^{1}$, Haneen Ali ${ }^{2}$ and Benjamin T Galen ${ }^{3 *}$ \\ ${ }^{1}$ Internal Medicine Residency Program, Mount Sinai School of Medicine, USA \\ ${ }^{2}$ Department of Radiology, Albert Einstein College of Medicine and Montefiore Medical Center, USA \\ ${ }^{3}$ Department of Internal Medicine, Albert Einstein College of Medicine and Montefiore Medical Center, USA
}

Submission: July 06, 2017; Published: July 26, 2017

*Corresponding author: Benjamin T Galen, Department of Internal Medicine, Albert Einstein College of Medicine and Montefiore Medical Center, Bronx, New York, USA, Tel: 718-904-2400; Fax: 718-904-2827; Email: BGalen@montefiore.org

Keywords: Coronary artery anomalies; Cardiac surgery; Chest pain

\section{Case Report}

A 59-year-old woman with a history of hypertension and mild asthma was brought to the emergency department complaining of acute onset chest pain. Electrocardiogram en-route by EMS showed ST-segment elevations in inferior leads, which normalized on arrival to the emergency department thirty minutes later. Initial serum troponin-T was $0.12 \mathrm{ng} / \mathrm{ml}$ (reference range: $0.0-0.1 \mathrm{ng} / \mathrm{ml}$ ). Coronary angiography revealed a suspected culprit, apical "wraparound" distal LAD stenosis with vasospasm and a difficult to engage right coronary artery (RCA) with $40 \%$ ostial stenosis. Her symptoms improved with intravenous nitroglycerin. Coronary computed tomography angiography showed an anomalous RCA arising from a separate origin in the left sinus of valsalva, with an "intramural" (within the wall of the aorta) and "inter-arterial" course (between the aorta and pulmonary artery) (Figure 1 \& 2). Given that the patient's EKG findings and presentation could also have been due to RCA compression and that the inter-arterial course of an anomylous RCA has historically been associated with a poor prognosis (even sudden cardiac death), she was referred for surgery $[1,2]$. The patient did well with a single vessel bypass of the RCA with a saphenous vein graft without recurrent chest symptoms.

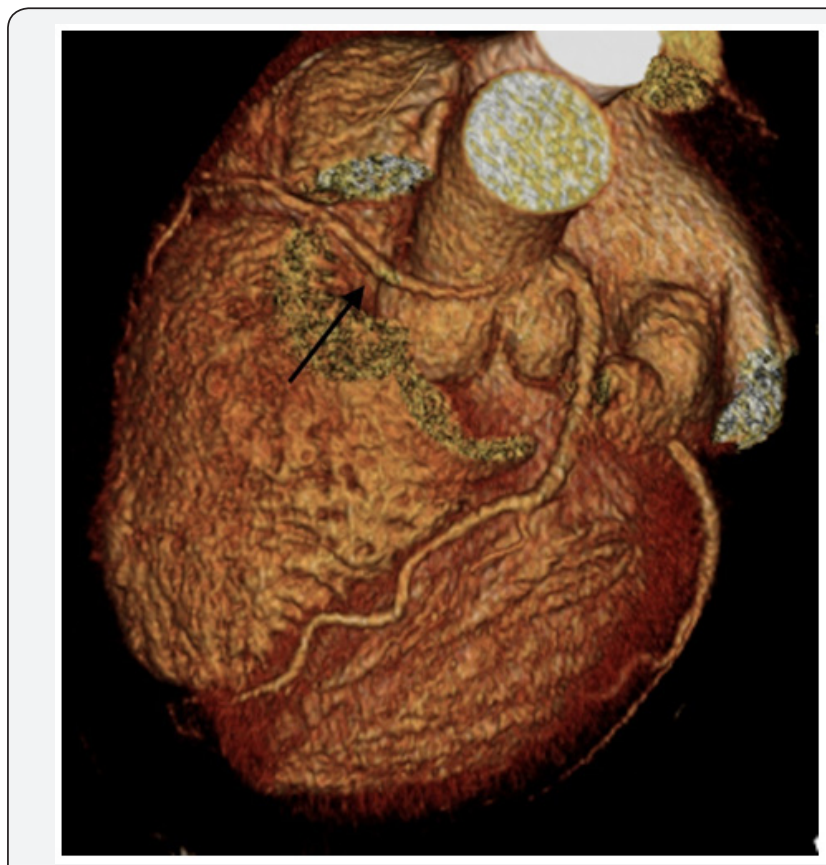

Figure 1: $3 D$ volume rendered reconstruction of the heart and coronary arteries (RCA at arrow). The right ventricular outflow tract has been partially removed for better visualization of the coronary arteries. 

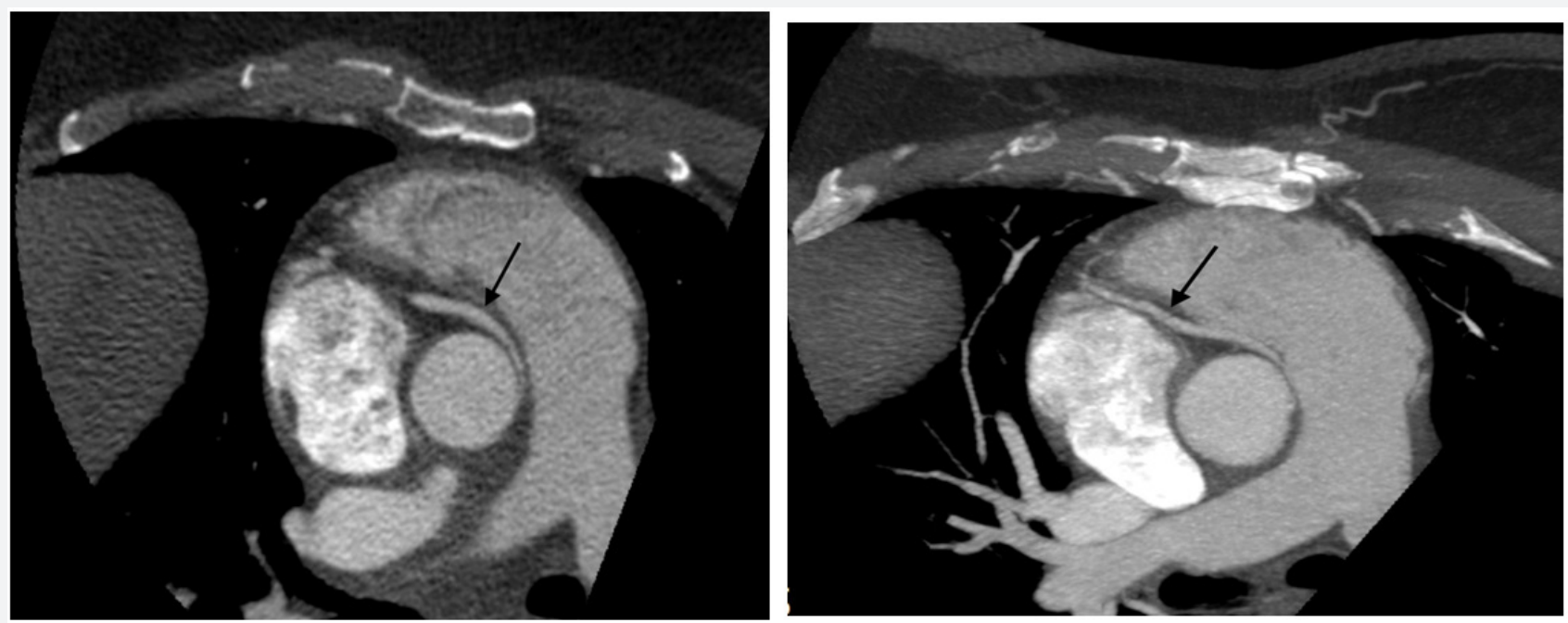

Figure 2: Corresponding axial images of the right coronary artery at two levels (black arrows).

\section{References}

1. Angelini P (2007) Coronary artery anomalies: an entity in search of an identity. Circulation 115(10): 1296-1305.
2. Krasuski R, Magyar D, Hart S, Kalahasti V, Lorber R, et al. (2011) LongTerm outcome and impact of surgery on adults with coronary arteries originating from the opposite coronary cusp. Circulation 123(2): 154162.

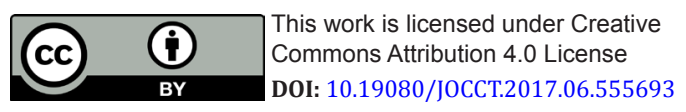

\section{Your next submission with Juniper Publishers} will reach you the below assets

- Quality Editorial service

- Swift Peer Review

- Reprints availability

- E-prints Service

- Manuscript Podcast for convenient understanding

- Global attainment for your research

- Manuscript accessibility in different formats ( Pdf, E-pub, Full Text, Audio)

- Unceasing customer service

Track the below URL for one-step submission https://juniperpublishers.com/online-submission.php 